\title{
Profil Kemampuan Berpikir Kreatif Siswa Menggunakan Soal Tes Pilihan Ganda pada Pembelajaran Ilmu Pengetahuan Alam
}

\author{
Alifia Kurnia $^{1 *}$, Sukarmin $^{1}$, Widha Sunarno ${ }^{1}$ \\ 1. Fakultas Keguruan dan Ilmu Pendidikan, Universitas Sebelas Maret \\ *email: niaalifia@student.uns.ac.id \\ Received: 26-07-2021; Reviewed:03-09-2021; Accepted: 21-09-2021
}

\begin{abstract}
Abstrak
Tujuan penelitian ini adalah untuk mengetahui profil kemampuan berpikir kreatif siswa pada pembelajaran IPA di kelas VIII SMP. Penelitian ini menggunakan metode deskriptif kuantitatif. Pengumpulan data dilakukan dengan menggunakan open-ended tes pilihan ganda berdasarkan indikator kemampuan berpikir kreatif. Instrumen tes telah divalidasi oleh ahli evaluasi pembelajaran. Keandalan dari tes ditentukan menggunakan rumus Alpha-Cronbach. Tingkat kesulitan dan daya beda juga digunakan sebagai parameter butir pengembangan instrumen tes dalam penelitian ini. Sampel pada penelitian ini adalah semua siswa kelas VIII di SMP Negeri 15 Surakarta berjumlah 242 siswa yang dipilih melalui teknik purposive sampling untuk mengidentifikasi kemampuan berpikir kreatif siswa. Hasil penelitian menunjukkan bahwa kemampuan berpikir kreatif siswa pada masing-masing indikator adalah Fluency 39,81\% berada pada kategori rendah, 45,87\% Flexibility berada pada kategori rendah, 38,02\% Originality berada pada kategori rendah, dan $35,67 \%$ Elaboration juga termasuk dalam kategori rendah. Kesimpulan yang didapatkan adalah kemampuan berpikir kreatif siswa masih berada pada kategori rendah, sehingga perlu adanya cara untuk meningkatkannya.
\end{abstract}

Kata Kunci : Kemampuan Berpikir Kreatif, Pilihan Ganda, Tes

\begin{abstract}
This study aim to determine the profile of students' creative thinking skills in learning science in class VIII SMP. The research method used is descriptive quantitative. Data was collected using an open-ended multiple choice test based on indicators of creative thinking ability. The test instrument has been validated by learning evaluation experts. The reliability of the test was determined using the Alpha-Cronbach formula. The level of difficulty and distinguishing power are also used as parameters for the development of test instruments in this study. The sample in this study was all students of class VIII at SMP Negeri 15 Surakarta totaling 242 students who were selected through purposive sampling technique to identify students' creative thinking abilities. The results of this study indicate that students' creative thinking abilities on each indicator are Fluency $39.81 \%$ in the low category, $45.87 \%$ Flexibility in the low category, $38.02 \%$ Originality in the low category, and 35.67\% Elaboration is also included in the low category. The conclusion obtained is that students' creative thinking skills are still in the low category, so there needs to be a way to improve it.
\end{abstract}

Keywords : Creative Thinking Skills, Test, Multiple Choice

\section{PENDAHULUAN}

Tuntutan perubahan mindset manusia abad 21 menurut Trilling and Hood (1999) adalah mempersiapkan diri agar dapat hidup dan bekerja dalam masa pengetahuan (knowledge age) khususnya pada bidang pendidikan. Pendidikan yang kuat dapat meningkatkan kualitas hidup (Trilling, 2009). Pada abad 21, keterampilan berpikir tingkat tinggi memiliki nilai-nilai strategis untuk diterapkan. Para pendidik dan siswa dituntut untuk memiliki kemampuan belajar mengajar abad 21. Keterampilan abad 21 yang dimaksud meliputi berpikir kritis, keterampilan kolaboratif, komunikasi, dan berpikir kreatif. Semua negara dari kategori miskin, berkembang, dan maju membutuhkan kemampuan untuk mengembangkan pemikiran kreatif (Freudenberg, 2011). 
Kemampuan berpikir kreatif memiliki peran strategis dalam kemajuan ilmu pengetahuan dan teknologi. Kreativitas sebagai hasil dari proses berpikir kreatif, memiliki kualitas sebagai aktivitas kognitif yang menghasilkan pemecahan masalah (Anwar, 2012). Semua negara baik negara miskin, negara berkembang maupun negara maju membutuhkan kemampuan untuk mengembangkan creative thinking (Freudenberg, 2011). Kemampuan berpikir kreatif adalah salah satu komponen kognitif siswa yang dapat menunjang keberhasilannya. Berpikir kreatif didefinisikan sebagai aktivitas mental yang digunakan untuk membangun gagasan atau ide baru (Siswono, 2008). Berpikir kreatif merupakan salah satu kemampuan berpikir tingkat tinggi. Hal ini sesuai dengan pernyataan penelitian terdahulu yang dilakukan peneliti bahwa "Keterampilan berpikir tingkat tinggi meliputi berpikir kritis, logis, reflektif, metakognitif dan kreatif" (King, 2009).

Keterampilan berpikir kreatif merupakan proses berpikir yang memungkinkan siswa untuk menerapkan imajinasi mereka dalam menghasilkan ide-ide, pertanyaan dan hipotesis, bereksperimen dengan konseptual alternatif dan untuk mengevaluasi ide-ide, proses serta implikasi produk. (Kamplylis, 2014). Keterampilan berpikir kreatif berhubungan dengan menemukan sesuatu serta menghasilkan sesuatu baru dengan menggunakan sesuatu yang sudah ada (Dariyanto, 2014). Hasil pemikiran tersebut dapat diberikan dalam bentuk gagasan nyata dan abstrak. Keterampilan berpikir kreatif selalu dikaitkan dengan keunikan atau berbeda dari yang lain karena keterampilan berpikir kreatif merupakan murni hasil pemikiran seseorang, oleh karena itu keterampilan berpikir kreatif identik dengan orisinalitas (Massoudil, 2003). Sub dimensi keterampilan berpikir kreatif dalam proses pembelajaran menurut Guilford meliputi beberapa indikator antara lain fluency (kemampuan menghasilkan banyak ide, jawaban, pemecahan masalah, atau pertanyaan), flexiblity (kemampuan menghasilkan ide bervariasi dari informasi yang telah diperoleh), originality (menghasilkan ide atau gagasan yang baru dan berbeda dari sebelumnya) dan elaboration (kemampuan untuk mengembangkan dan menambahkan ide secara detail sehingga tampak lebih menarik) (Guilford, 1975). Keterampilan berpikir kreatif dapat dibentuk melalui tahapan berpikir divergen. Tahap proses dalam berpikir kreatif meliputi persiapan, inkubasi, iluminasi dan verifikasi atau evaluasi (Sitorus, 2016). Kreativitas dapat dipertahankan oleh pengajar dan lingkungan belajar yang mendorong pertanyaan, terbuka terhadap ide baru, dan belajar dari kesalahan atau kegagalan (Trilling, 2009).

Berpikir kreatif masih sulit untuk didefinisikan dalam konteks pembelajaran IPA, namun peneliti percaya bahwa itu adalah bagian dari proses kognitif yang dapat dikembangkan melalui desain pembelajaran yang memadai (Scott, Leritz, \& Mumford, 2004). Kajian tentang pengukuran keterampilan berpikir kreatif belum banyak dilakukan. Kajian terkait keterampilan berpikir kreatif di negara-negara India, Israel, Hong Kong, Jerman, dan Rumania masih tergolong rendah, sehingga penting untuk dilakukan kajian lebih lanjut sebagai kontribusi bagi pendidik, siswa, dan pendidikan (Hürsen, 2014) Meskipun sulit untuk menilai kreativitas, terdapat beberapa instrumen dan penilaian yang telah dirancang untuk mengukur kreativitas dalam bidang tertentu (Pacific Policy Research Center, 2010) Kajian untuk mengetahui profil awal siswa dapat dilakukan dengan berbagai cara tergantung dari kategori atau dimensi yang dipelajari. Pengkajian kemampuan berpikir kreatif siswa sebagai profil awal sangat penting karena memiliki kaitan yang kuat dengan adanya kontribusi strategis. Penilaian awal kompetensi siswa dalam mengatasi kesulitan belajar dapat dilakukan dengan menganalisis profil awal kemampuan berpikir kreatif siswa.

\section{Metode}


Penelitian ini merupakan penelitian deskriptif kuantitatif. Metode tes dipilih untuk mendeskripsikan persentase kemampuan berpikir kreatif pada siswa kelas VIII SMP Negeri 15 Surakarta, Jawa Tengah, Indonesia. Sampel dalam penelitian ini adalah 242 siswa yang terdiri dari seluruh siswa kelas VIII di SMP Negeri 15 Surakarta yang dipilih melalui teknik purposive sampling dengan tujuan untuk mengetahui kemampuan berpikir kreatif siswa. Siswa diberikan tes untuk menganalisis kemampuan berpikir kreatifnya dalam pembelajaran IPA. Tes yang diberikan berupa tes pilihan ganda terbuka dengan soal yang telah dikembangkan dengan indikator kemampuan berpikir kreatif yang sebelumnya dilakukan validasi ahli evaluasi pembelajaran. Tes diberikan secara online melalui google form karena kondisi pandemic covid-19 yang membuat siswa harus belajar dari rumah. Reliabilitas tes ditentukan dengan menggunakan rumus AlphaCronbach. Tingkat kesulitan dan daya pembeda juga digunakan sebagai parameter item atau tes yang digunakan. Topik IPA dalam soal tersebut meliputi fenomena kehidupan sehari-hari mengenai getaran dan gelombang. Penilaian dari tes pilihan ganda dan rubrik terbuka yang telah divalidasi oleh ahli dari masing-masing indikator. Selanjutnya data tes dianalisis dengan persentase untuk mengetahui indikator kemampuan berpikir kreatif siswa yang belum tuntas dengan menggunakan rumus:

$$
\text { Persentase }(\%)=\frac{\text { Skor setiap indikator }}{\text { Skor total setiap indikator }} \times 100 \%
$$

Data yang diperoleh selanjutnya dianalisis dengan menghitung persentase skor yang diperoleh siswa pada setiap indikator keterampilan berpikir kreatif.

\section{Hasil dan Pembahasan}

Penelitian ini dilakukan untuk menganalisis profil awal kemampuan berpikir kreatif siswa. Profil awal kemampuan berpikir kreatif siswa diwakili oleh empat indikator yang terdapat dalam soal, antara lain Fluency, Flexibility, Originality, dan Elaboration. Soal tes yang digunakan berupa tes pilihan ganda open-ended berbasis kemampuan berpikir kreatif yang telah divalidasi oleh tim ahli evaluasi. Validitas butir soal ditentukan dengan menggunakan rumus Karl-Pearson terkait dengan koefisien korelasi product moment. Reliabilitas tes ditentukan dengan menggunakan rumus Alpha-Cronbach. Tingkat kesulitan dan daya pembeda juga digunakan sebagai parameter item. Hasil tes profil awal siswa disajikan pada Tabel 1 sedangkan analisis hasil tes mengacu pada kriteria tingkat berpikir kreatif menurut (Shriki, 2013) disajikan pada Tabel 2. Tabel 1 menunjukkan tingkat kemampuan berpikir kreatif siswa pada setiap indikator. Hasil penelitian menunjukkan bahwa siswa mempunyai keterampilan berpikir kreatif yang rendah berdasarkan kriteria yang terdapat pada Tabel 2.

Tabel 1. Profil kemampuan berpikir kreatif siswa

\begin{tabular}{lcc}
\hline Indikator & Persentase $\mathbf{( \% )}$ & Kriteria \\
\hline Fluency & 39,81 & Rendah \\
Flexibility & 45,87 & Rendah \\
Originality & 38,02 & Rendah \\
Elaboration & 35,67 & Rendah \\
\hline Rata-Rata & 39,84 & Rendah \\
\hline
\end{tabular}

Table 2. Kategori Kemampuan Berpikir Kreatif 


\begin{tabular}{cc}
\hline Persentase & Kategori \\
\hline$<55 \%$ & Rendah \\
$\leq 55 \%-<75 \%$ & Sedang \\
$\geq 75 \%$ & Tinggi \\
\hline
\end{tabular}

Hasil penelitian ini menunjukkan bahwa kemampuan berpikir kreatif siswa pada indikator Fluency $39,81 \%$ berada pada kategori rendah, 45,87\% Flexibility yang berada pada kategori rendah, $38,02 \%$ Originality berada pada kategori rendah, dan 35,67\% Elaboration termasuk dalam kategori rendah. Berdasarkan hasil uji profil awal, kemampuan berpikir kreatif belum mencapai skor ideal. Temuan ini sejalan dengan beberapa penelitian sebelumnya yang menunjukkan rendahnya kemampuan berpikir kreatif siswa di Indonesia. Sementara itu, kemampuan berpikir kreatif siswa kategori rendah ternyata tidak hanya muncul dalam skala nasional. Gambar 1 menunjukkan persentase kemampuan berpikir kreatif siswa pada tiap indikator.

Hasil observasi yang dilakukan di SMP Negeri 15 Surakarta didapatkan bahwa guru belum memberdayakan keterampilan berpikir kreatif sehingga keterampilan berpikir kreatif siswa masih tergolong rendah. Rendahnya kemampuan berpikir kreatif siswa di SMP N 15 Surakarta diakibatkan karena selama ini proses pembalajaran IPA belum melatihkan siswa untuk berpikir secara divergen, yaitu berpikir kreatif yang dapat menggunakan informasi sebanyak mungkin. Hal ini sesuai dengan temuan Rofi'udin yang mengatakan adanya keluhan dan kurangnya keterampilan berpikir kreatif yang dimiliki oleh lulusan pendidikan dasar hingga perguruan tinggi karena keterampilan berpikir belum ditangani dengan baik (Rofi'udin, 2000). Pembelajaran untuk meningkatkan kemampuan berpikir kreatif di sekolah jenjang selanjutnya perlu diintegrasikan pada setiap mata pelajaran, termasuk mata pelajaran IPA apapun topiknya. Penelitian serupa juga menemukan adanya penurunan kemampuan berpikir kreatif siswa di Prancis (Georgsdottir \& Lubart , 2003). Menurut penelitian sebelumnya, pencapaian yang rendah atau tidak memuaskan pada tiga kriteria lainnya meliputi fleksibilitas, elaborasi, dan orisinalitas (Tran, et al, 2003).

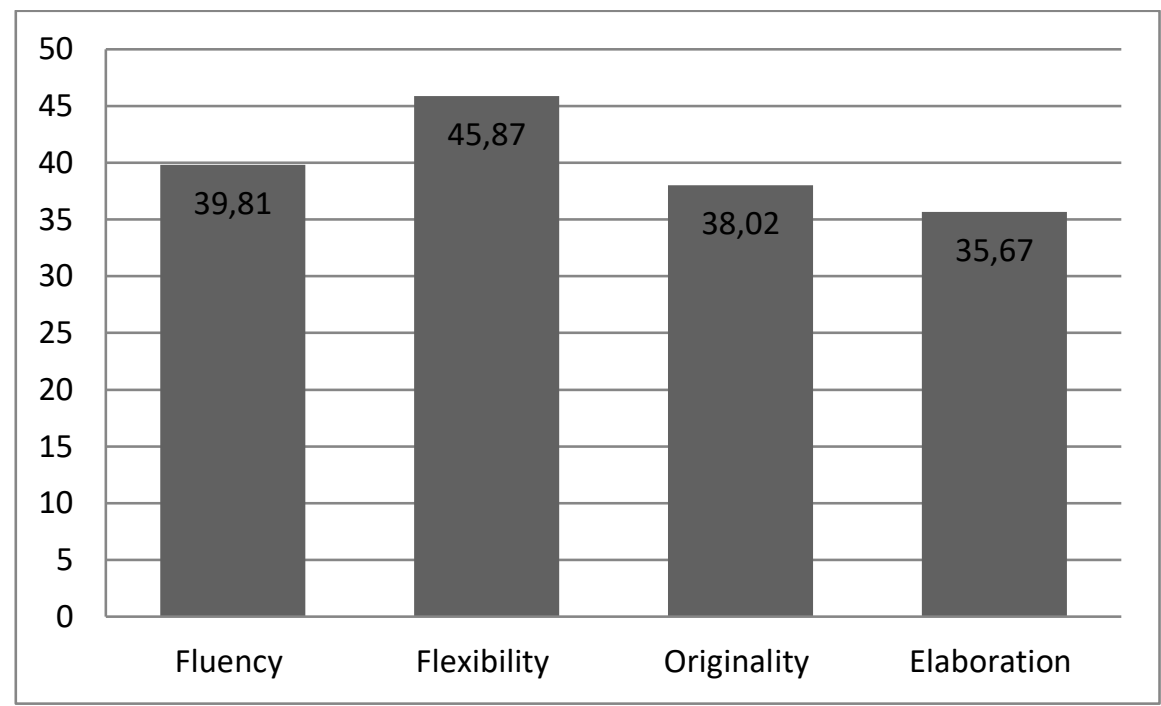

Gambar 1. Persentase kemampuan berpikir kreatif siswa

Berdasarkan uraian tersebut ditunjukkan, ada hasil bahwa cara berpikir siswa belum terlatih secara optimal, terutama ketika mereka diminta untuk berpikir kreatif. Oleh karena itu, penting untuk memberdayakan keterampilan berpikir kreatif dalam pembelajaran, khususnya pada mata pelajaran IPA. 


\section{Kesimpulan}

Berdasarkan penelitian yang telah dilakukan menunjukkan bahwa kemampuan berpikir kreatif siswa kelas VIII SMP N 15 Surakarta dalam pembelajaran IPA masih tergolong rendah. Berdasarkan analisis yang telah dilakukan terlihat bahwa kemampuan berpikir kreatif siswa pada masing-masing indikator adalah indikator Fluency sebesar 39,81\%, sebesar 45,87\% pada indikator Flexibility indikator Originality memiliki persentase 38,02\% dan 35,67\% Elaboration. Hasil ini menunjukkan bahwa perlunya pemberdayaan pada kemampuan berpikir kreatif siswa. Adapun saran yang dapat disampaikan terkait penelitian ini yaitu dengan melaksanakan penelitian lanjutan sebagai upaya untuk memberdayakan kemampuan berpikir kreatif pada pembelajaran IPA selain itu hasil penelitian ini dapat digunakan sebagai acuan kepustakaan untuk penelitian berikutnya yang sejenis dengan penekanan pada pencapaian kompetensi abad 21 selain kreativitas.

\section{Referensi}

Anwar M N, Shamim-ur-Rasool S and Haq R. (2012). A comparasion of Creative Thinking skills of High and Low Achievevers Secondary School Student International. Interdisciplinary Journal of Education, 1(1), 3-8

Dariyanto. (2009) Panduan Proses Belajar Kreatif dan Inovatif. Jakarta: Buku yang Cerdas dan Mencerdaskan

Freudenberg B, Brimble M and Cameron C. (2011). Work-integrated learning and generic skill development: The development of business students' generic skills through workintegrated learning. Asia-Pacific Journal of Cooperative Education, 12(2), 79-93

Georgsdottir, A., \& Lubart, T.I. (2003). La flexibilité cognitive et la créativité : [Cognitive flexibility and creativity]. Psychologie Française [French Psychology], 48(3), 29-40

Kampylis, P. \& Berki, E. (2014). Nurturing Creative Thinking. International Academy Of Education.

Massoudil M. (2003). Can scientific writing be creative?. Journal of Science Education and Technology. 12(2), 115-28.

Pacific Policy Research Center. 2010. 21st Century Skills for Students and Teachers. Honolulu: Kamehameha Schools, Research \& Evaluation Division.

Rofi'uddin, A. (2000). Model Pendidikan Berpikir Kritis Kreatif untuk Siswa Sekolah Dasar. Majalah Bahasa dan Seni 1 (28): 72-94

Scott, G., Leritz, L. E., \& Mumford, M. D. (2004). The Effectiveness of Creativity Training: A Quantitative Review. Creativity Research Journal, 16(4), 361-388.

Shriki A. (2013). A model for assessing the development of students' creativity in the context of problem posing. Creative Education, 4(7), 430-39 
Siswono T Y E. (2008). Model Pembelajaran Matematika Berbasis Pengajuan dan Pemecahan Masalah untuk Meningkatkan Kemampuan Berpikir Kreatif. Surabaya: Universitas Negeri Surabaya

Sitorus J \& Masrayati. (2016). Student's Creative Thinking Process Stages: Implementation of Realistic Mathmatics Education. Thinking skills and Creativity, 22, 111-20

Tran T B L, Ho T N, Mackenzie S V \& Le L K. (2017). Developing assessment criteria of a lesson for creativity to promote teaching for creativity. Thinking Skills and Creativity, 25, 10-26

Trilling B and Fadel C. (2009). 21 st Century Skills, Learning for Life in our Times. San Francisco: Jossey-Bass

Wijaya, dkk. (2016). "Pengembangan Kemampuan Berpikir Kritis Matematis Siswa melalui Strategi Pembelajaran Thingking Aloud Pair Problem Solving”. Prosiding Konferensi Nasional Penelitian Matematika dan Pembelajaran (KNMP I) Universitas Muhammadiyah Surakarta, 210-215 